\title{
ЯЗЫКОВАЯ ЛИЧНОСТЬ НОСИТЕЛЯ МОЛОДЁЖНОГО СЛЕНГА
}

\section{LANGUAGE PERSONALITY OF THE BEARER OF YOUTH SLANG}

Zhang Wei

Summary: Expanding the field of study of cultural linguistics determines the relevance of this topic. In this work, we analyze modern Russian youth slang from the point of view of the linguistic personality of its carrier. In addition, the analysis of the linguistic personality of the speaker of modern Russian youth slang exactly coincides with the key idea of modern linguistics, the idea of the anthropocentricity of language.

Keywords: youth slang, linguistic personality, carrier of youth slang, modern linguistics.

\author{
Чжан Вэй \\ Аспирант, Рязанский государственный университет \\ им. С.А. Есенина; преподаватель, \\ Чанчуньский научно-технический институт \\ xiaotuzhangwei@163.com
}

Аннотация: Расширение области исследования лингвокультурологии определяет актуальность настоящей темы. В данной работе мы анализируем современный русский молодёжный сленг с точки зрения языковой личности его носителя. Кроме того, анализ языковой личности носителя современного русского молодёжного сленга как раз и совпадает с ключевой идеей современной лингвистики, идеей антропоцентричности языка.

Ключевые слова: молодёжный сленг, языковая личность, носитель молодёжного сленга, современная лингвистика.
$\Pi$ режде всего, необходимо дать определение понятию сленга. Это выражение, которое используется группой людей, имеющих общие интересы, определенный социальный статус или объединенных единым занятием. Согласно определению исследователя В.А. Хомякова, это специфичный лексический пласт, который находится вне литературного языка, разговорной лексики, различного рода диалектов. Характерными чертами сленга, по мнению В.А. Хомякова, являются фразеология профессиональных диалектов, фразеология нелитературного стиля языка и общепонятная лексика [1].

Молодёжный сленг - активный словарный запас в современном русском языке, действительно отличается многообразием, сложностью в структурном отношении, богатством словообразовательных форм. Он обслуживает практически все сферы человеческой деятельности, его лексемы обладают сильной эмоциональной окрашенностью.

Необходимо согласиться с тем, что основной функцией молодёжного сленга является именно экспрессивная. Однако если обратиться к его источникам, станет очевидным, что какую бы эмоциональную оценку ни хотел выразить носитель этого подъязыка, речи его носителей выражает языковая личность в лингвистике.

Другой русский филолог - Ю.Н. Караулов позиционирует языковую личность как совокупность свойств и способностей человека, которые определяют восприятие и образование им текстов, при этом каждый текст характеризуется определенной степенью структурно-языковой сложности, точностью выражения и передачи окружающей действительности, целевой направленностью. Таким образом, языковая личность понимается и пози- ционируется как продолжение понятия «личность». Исследователь придерживается позиции, что стандартные психологические исследования личностной проблематики концентрируются на «не когнитивных аспектах», а не на «интеллекте и способностях» [2]. Интеллект людей отражается в языке. «Языковая личность включает два аспекта: «язык, на котором говорит человек» и «человек в языке». За каждым текстом существует языковая личность (человек). Факторы и человеческий фактор вместе составляют «языковую личность». Поскольку языковая личность Караулова относится как к «языку, на котором говорят люди», так и к «людям в языке», мы полагаем, что она также может относиться к языку групп, при этом этническо-конкретные объекты исследования языковой личности могут включать следующие два аспекта:

1. Как «язык, на котором говорят люди». Он может относиться к языку писателей и политиков, он также может относиться к языку людей разного возраста и пола.

2. Быть «человеком в языке» - это, в свою очередь, исследование предмета языка. Это может быть субъект языка, который думает о реальном мире; он может быть автором определенного текста; он также может быть человеком, говорящим на определенном языке; конечно, это может быть определенная группа или определенная этническая группа.

Кроме того, Чжао Айго, известный русский учёный в Китае, также указал, что языковая личность - это теория для изучения отношений между «людьми» и «языком». Такая языковая личность относится к языковым когнитивным способностям людей, включая картину мира и язык. Сознание, национальный разум, ассоциативное поле, внутренний лексикон, психолингвистический экс- 
перимент, прецедентный феномен и другие очень широкие темы и содержание исследования. Эта статья поддерживает эту точку зрения. Таким образом, языковая личность - это «личность, воплощенная в языке (тексте) и посредством него», или «личность, построенная на языковых средствах». 7\% -ное исследование языковой личности представляет собой многомерное и трехмерное исследование использования языка, людей, говорящих на нем, и языкового познания.

В Китае термин «личность», восходит к слову, обозначающую маску, которую носил театральный актер Древнего Рима. В настоящее время данная дефиниция обычно характеризуется как личностное стабильное психологическое качество, включающее два аспекта, а именно: личные мотивации (относящиеся к потребностям, побуждениям, интересам и убеждениям человека и т. д., определяет отношение, склонность и выбор людей к действительности), а также психологические характеристики личности (имеются в виду способности, темперамент и личность человека, которые определяют личностные особенности поведения человека). Органическое сочетание этих двух аспектов составляет общую структуру личности [2]. Не трудно видно, что русские и китайские учёные считаются, что вопрос личности символ одного или группового характера.

Языковая личность предполагается нами в первую очередь как носитель языка. В принципе носители молодёжного сленга - это учащиеся или студенты, школьники старших классов или молодые рабочие, отчасти молодая техническая и гуманитарная интеллигенция в возрасте примерно от 22-23 до 33-35 лет.

По вопросу о носителе молодёжного сленга, у китайских учёных есть своё мнение. Учёные Чжао Вэй и Жун Цзе считают, что в связи с изменением возрастной категории и другими социальными факторами, определение возрастной группы для молодых сленговых пользователей было также изменено, установленный возраст 13-35 лет. По поводу носителя молодёжного сленга, китайские и российские исследователи имеют собственное мнение, но стоит отметить: к молодежи относятся люди не больше 35 лет. Но с развитием общества и информационной техники возраст говорящих на молодёжном сленге не определён, бывают больше 35 лет используют молодёжными сленговыми лексиконами [3].

Современный сленг молодежи можно условно разделить на две категории:

1. Общешкольный. Понятие любому человеку, являющемуся членом или участником той или иной группы. Как правило, он понятен учащимся всего образовательного учреждения.

2. Групповой. Подчеркивает принадлежность конкретного человека к той или иной группе, тече- нию, молодежному движению [4].

В первую группу входят слова двух типов. Первый тип - это слова и словосочетания, обозначающие школьные (институтские, университетские и т. д.) реалии, своеобразная игра со всем известными названиями. Слова этого типа практически не изменились на протяжении последнего десятилетия. Вот несколько примеров: академ (академический отпуск), автомат (зачёт или экзамен, которые ставятся без ответа студента в связи с хорошей посещаемостью и ответом на семинарах, аквариум (место в корпусе № 4 на этаже философского факультета), абитуха, (абитуриенты), бандиты (студенты экономического факультета), блевок (студенческая столовая), блокпост (вахта в общежитии), братан (одногруппник, друг), вахта (ежегодная традиционная вечеринка факультета журналистики), вышка (высшая математика), гастриловка (студенческая столовая), госы (государственные экзамены), домашка (домашнее задание), забить на пару (прогулять лекцию), завалить (не сдать), курсач (курсовая работа), общага (общежитие), хвост (несданный зачёт, экзамен), препод (преподаватель, чаще всего в вузе), стипуха (стипендия), шпора (шпаргалка) и т.д.

К данной же категории относятся клички и прозвища профессорско-преподавательского состава. В данном случае приводить примеры будет нецелесообразно, так как нет каких-либо устойчивых универсальных выражений и форм. Однако существует ряд общих схем и механизмов, с помощью которых составляются прозвища и клички. Как правило, это либо обыгрывание манеры речи, особенностей внешности и характера, либо обыгрывание фамилий, имен и отчеств [5].

Заимствования в молодёжном сленге выражают большое внимание молодёжи, среди них особое положение занимают заимствования из английского языка [6]. Молодые люди считаются, что функции заимствования: пополнение языка более выразительными средствами; восприятие иноязычного слова как более престижного; необходимость конкретизации значения слова. С развитием информационной техникой люди употребляют программу сети, больше и больше неологизмов существуют. Ведут примеры такие: хайп (шумиха, ажиотаж), от английского hуре, хейтер (недруг), от английского to hate, чилить (отдыхать, ничего не делать), от английского to chill, изи (легко, полегче), от английского easy, агриться (злиться, раздражаться), от английского angry, го (идём, давай), от английского to go, свайп (скользить пальцем по экрану), от английского to swype, бодишейминг (критика внешности), от английского body shaming, бодипозитив (приятие любых тел; явление, обратное бодишеймингу), от английского body positive, гамать (играть), от английского game, краудфандинг (сбор денег в Интернете), от английского crowd, бинджвотчинг («запойный» просмотр сериалов), от английского binge 
(запой) watching (просмотр), фуди (гурманы), от английского food, фо рилзис (действительно ли), от английского сленгового forrealsies, юзать (пользоваться), от английского to use, стримить (передавать данные (видео, звук) в реальном времени), от английского streaming.

При помощи английского заимствования, живая речь - молодёжный сленг является яркой характеристикой личности человек и его индивидуальности. Выражая свои мысли точнее и интереснее, человек приобретает больше шансов. Быть услышанными на работе, среди друзей и знакомых. И суть ее состоит в том, что сленг является своего рода паролем, позволяющим опознать «своего» среди прочих (по манере разговора, жестам и др.), он облегчает поиск нужных лиц, помогает устанавливать и поддерживать специфические контакты.

Итак, важной для молодёжного сленга является идентификационная функция. Благодаря ей говорящий сигнализирует о своей социальной принадлежности к определенному языковому коллективу.

Мы заметили, что подобные слова характеризуют юмористическую и живую языковую личность студентов, отражая их университетские будни и быт. Существует достаточно большое количество сленговой лексики, которая подчеркивает юмор, иронию, эмоциональность и виртуальность речи студентов.

Культура оказывает несомненное воздействие на язык, в современном мире активно распространяются англицизмы и американизмы, которые проникают и в русский язык. Например: вайфаиться или вафля (WI-FI), боди (тело), бэйби (дети), бука (книга), бойфренд (друг), ботл (стакан), бас (автобус) геймер (игра), кэш (наличные), юзер (абонент), логин (идентификатор пользователя для входа в интернет-сервисы), лузер (неудачник), комп (компьютер), шопинг (покупка), тейбл (стол), фейс (лицо), прайс (цена), шуза (обувь), ньюс (новость), спич (выступление), сайз (размер), соксы (носки), супербл (больной, огромный, крупный, великий), тича (учитель) и т.д.

Ю.Н. Караулов определяет три основных уровня языковой личности. Рассмотрим каждый из них более подробно:

1. Вербально-семантический. Является выражением степени владения разговорной речью, в которой в качестве главных единиц используются слова, отношения между которыми выражаются в форме синтаксических, грамматических и парадигматических связей.

2. Когнитивный. Главным определением данного уровня является использование разнообразных концепций, понятий и идей, выражающихся посредством нулевого уровня. Таким образом, отношения выстраиваются в определенную иерархию, являющуюся некой демонстрацией структуры мира. Когнитивный уровень подразумевает выражение языковой мировой модели личности.

3. Мотивационный. Определяется совокупность. Коммуникативных и деятельностных потребностей той или иной личности. Между данными категориями отношений при этом образуются специфичные коммуникативные сети. Образуемый стереотип прежде всего соответствует коммуникативным потребностям. Данный уровень содержит в себе определение целей и мотивов, которые являются определяющими для личностного развития в тех или иных условиях.

Определение уровней является условным, в реальной жизни зачастую они взаимосвязаны и включены друг в друга. В результате языковая личность выглядит определённым образом.

На первом уровне отмечается наличие огромного числа синонимических рядов, которые в свою очередь состоят из абсолютных синонимов. Особенности, которые проявляются на втором уровне: современное русское молодое поколение увлекается собой в быту, в развлечениях, в досуге. Они уделяют больше внимания деньгам, они неверны своей любви, но у них разные хобби и большие творческие способности. И мы считаем, что на прагматическом уровне современные русские молодые люди используют сленг в общении для идентификации, выражения чувства юмора и самовыражения.

Молодёжь употребляет такие сленгизмы в коммуникации для выражения оценки предмета или явления, для характеристики качества предмета, чтобы дать свою эмоциональную оценку предмету или событию более ярко, экспрессивно [7]. Кроме того, молодёжный сленг делится на групповую и профессиональную языковую личность. Молодёжь выражает свои эмоции через молодёжный сленг.

Использование сленга обусловлено, на наш взгляд, тремя причинами: идентификация говорящего с собеседниками (принадлежность к одной группе), комическое отношение к действительности, способ самовыражения. Знание сленга может помочь преподавателю понять студентов, разобраться из взаимоотношениях и отношениях внутри коллектива [8].

Молодёжь как инновационная группа, их язык не традиционный, а новый. И они всё время выражают «свой» язык, не «чужой». Узнавать языковую личность молодёжного сленга, может помочь студентам пополнить словарный запас русского языка, который отражает не только общерусский характеристики языкового типа, также тесно связаны с когнитивным и прагматическим уровнями языковой личности [9]. 
Живой язык - современный молодёжный сленг пребывает в статике и динамике одновременно, чтобы успешно удовлетворять коммуникативные эмоциональные потребности носителей языка [10]. Для нас стоит исследовать особенности языковой личности носителя современного русского молодежного сленга. Развитие современного молодежного сленга крайне многогранно. Он должен стать объектом пристального внимания учёных-языковедов. Молодежный сленг достаточно быстро обновляет свой лексический состав, пополняясь новыми единицами, языковая личность его носителя, и уже поэтому дальнейшие исследования в лингвокультурологии области могут привести к неожиданным и инте- ресным результатам.

В рамках основной модели международной коммуникации приобретение языковой личности в молодёжном сленге стало важной частью предотвращения недопонимания при общении и уменьшения культурных конфликтов. Теория языковой личности совпадает с картиной языкового мира и прецедентами. Теории языковой личности положительно влияют на межкультурное общение. Попытки овладеть языковой личностью молодёжного сленга и успокоить теорию языковой личности. Естественное применение в межкультурном общении может обеспечить плавный прогресс межкультурного общения.

\section{ЛИТЕРАТУРА}

1. Хомяков В.А. Нестандартная лексика в структуре английского языка национального периода: автореф. . . . канд. филол. наук. Л.,1980. С. 111

2. Караулов Ю.Н. Русский язык и языковая личность // Наука М., 1987. С.3

3. Чжао Вэй, Жун Цзе Русский сленг: история, статус и задача // Исследование иностранных языков Цзясу., 1998. С. 17

4. Анищенко 0.А. Генезис и функционирование молодежного социолекта в русском языке национального периода // Наука М., 2010. С.65

5. Береговская Э.М. Молодёжный сленг: формирование и функционирование // Вопросы языкознания М., 1996. №3. С.73

6. Гальперин И.Р. 0 термине «сленг» // Вопросы языкознания М., 1956. С.9

7. Евсюкова Т.В. Характерные особенности языковой личность студента // Гуманитарные, социально-экономические и общественные науки Ростов., 2015. С.176

8. Коськов М. А. Философия культуры и культурология: определение понятий // Вестник Лениградского государственного университета им А.С. Пушкина. Санкт-Петербург, 2012. С.23

9. Карасик В.И. Языковой круг: личность, концепты, дискурс // Научно-исследовательская лаборатория Аксиологическая Лингвистика Волгоград, 2002. С.21 10. Нетяго Н.В. Лексикология современного русского языка // ФЛИНТА М., 2017., С. 74.

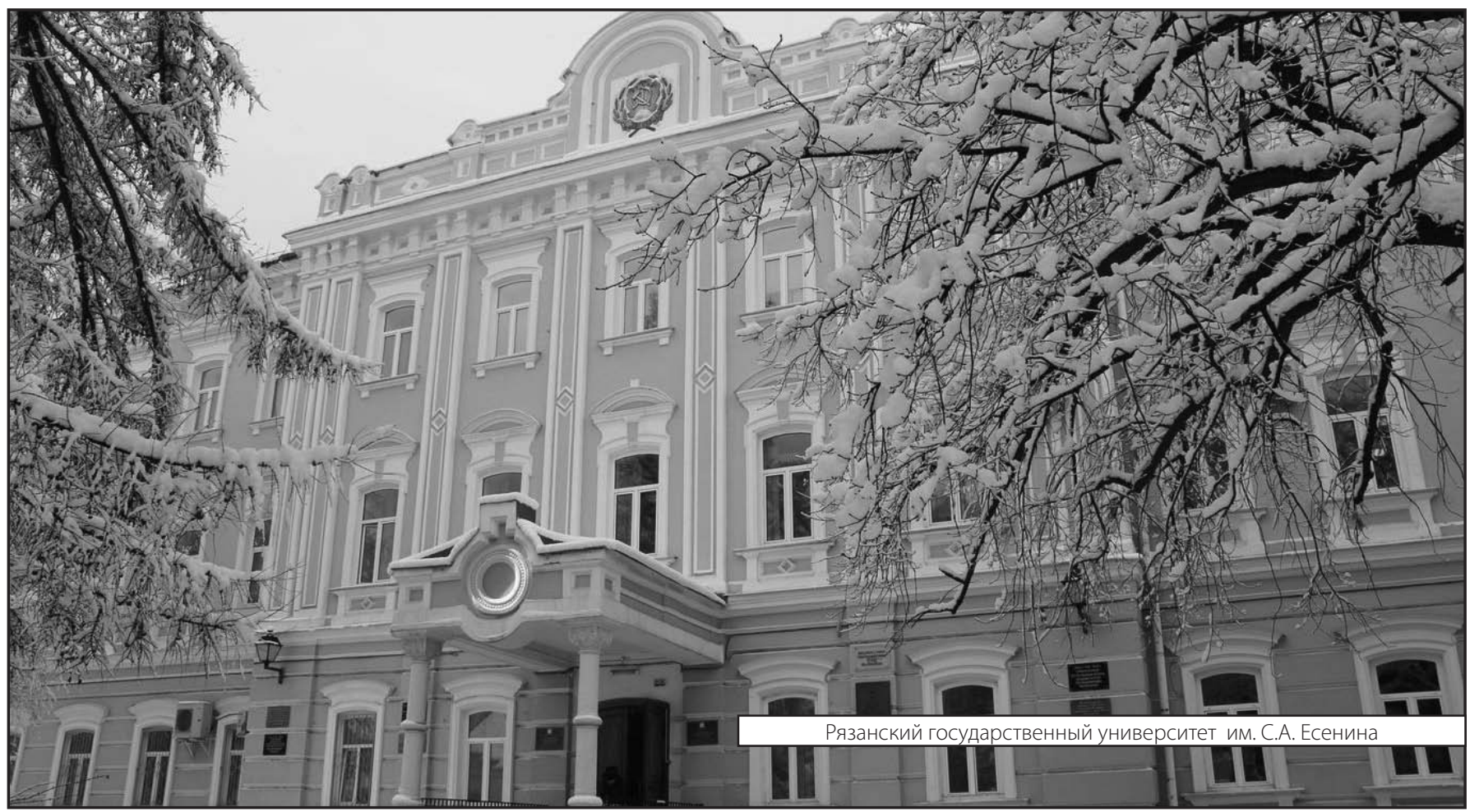

